\title{
Mentors seek to prove value for money
}

[WASHINGTON \& NEW YORK] Three years ago, the US Congress ended a \$15-million-a-year scheme by the Department of Energy to forge links between schoolteachers and scientists in its laboratories, after a report from the General Accounting Office (GAO) concluded that teaching science teachers about science was a waste of time and money.

This summer, hundreds of scientists will serve as mentors for schoolteachers who will spend their long vacation rediscovering science. Some are also seeking elusive data to prove the GAO wrong, and that teaching teachers about real science is an efficient way of raising school standards in science and mathematics.

In its report, GAO, the investigatory arm of Congress, attacked the energy department for concentrating resources on 'teacher enhancement' when, it said, 'research suggests that these projects may be ineffective at increasing student achievement". But advocates of summer programmes for teachers - including some of the United States' most prominent scientists - believe fervently that they do just that. The challenge is to produce the data to prove it.

Washington's Carnegie Institution has pioneered efforts to support schoolteachers. When Maxine Singer, then head of the biochemistry laboratory at the National Cancer Institute, became president of the institution in 1988, she quickly sought to open up its building to children from local schools. It was parents at the nearby Ross Elementary school who suggested that she should train the teachers as well.

This year, 100 elementary schoolteachers will spend six weeks at the institution during the summer under what is now a major programme funded by the National Science Foundation (NSF), called the Carnegie Academy for Science Education (CASE).

\section{Project-based experiments}

Singer says the institution focused on elementary schools, which teach 5-11-yearolds, because "by the time you get to middle school, most of the inner-city kids are already convinced that science and maths are not for them". The non-specialist teachers go to class with three science educators who have been hand-picked by Singer to run the programme, as well as a larger number of teachers who excelled at CASE in previous years and who are returning as mentors.

They learn project-based approaches to simple experimental problems - finding out what determines the period of a pendulum, for example. And they are taught to link their teaching approach to the National Science Education Standards produced last year by the National Research Council — favouring discovery over the repetition of facts.

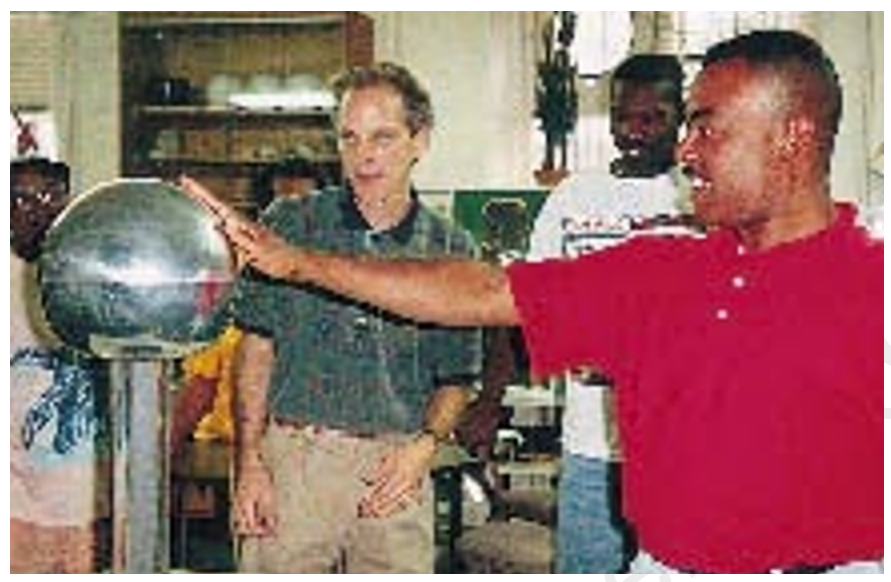

Hands-on experience: Charles James (left) is helping the Carnegie Institution in Washington to work with local schoolteachers under the sponsorship of the National Science Foundation during the long vacation to restimulate an active interest in and knowledge of science.

Alida James Fenner, one of the mentors and a teacher at Bunker Hill Elementary School in northeast Washington, says the course has entirely changed her approach to teaching science, and has led to its integration with other subjects, such as geography.

By the time it ends next year, 450 teachers will have attended CASE - a quarter of the elementary-school staff in the District of Columbia (DC) school system, one of the most troubled in the United States.

\section{Rediscovering real science}

Until recently, Carnegie had made little progress towards formal cooperation or support from the DC school board. But last year, Congress asked General Julius Beckton, a former Army commander, to take over responsibility for the system from the widely criticized board. Beckton has visited Carnegie several times, honoured the programme with a special award, and is now talking with Singer about a deal under which Carnegie will take responsibility for science and maths teacher training in the city's elementary schools.

About 90 smaller but more intensive programmes across the country are retraining high-school science teachers by giving them laboratory work experience. At Columbia University in New York, for example, ten teachers from local high schools are selected each year for two successive summers of hands-on experience in a research laboratory.

"This has been a very, very uplifting experience," says Edwin Klibaner, an experienced biology teacher at the John Dewey High School on Coney Island, South Brooklyn, who went through the scheme three years ago. "It reinforced the notion that I had the ability to do science - real science."

Klibaner now runs a biotechnology programme at John Dewey High. The Nobel laureate Joshua Lederberg of Rockefeller University was among those who helped Klibaner to design the programme. "I could not have had that kind of support and entry into the world of science without the programme," says Klibaner. "And if I didn't do this, no one else at the school would."

New York's school system is ten times the size of Washington's, and the city school board has shown little interest in supporting this kind of intensive professional development for its teachers. But every student undergoes annual standardized tests, called Regent's tests, providing one of the largest and most complete databases of student performance in the United States.

For Sam Silverstein, chair of physiology at Columbia's medical school, these data represent a unique opportunity for formally evaluating the scheme against the only yardstick that matters to politicians - student test performance. Early assessments have shown positive trends in both attendance and Regent's test scores; but statisticians at Columbia point out that the number of teachers in the initial sample is too small to produce statistically significant results.

\section{But does it improve teaching?}

Silverstein, in collaboration with the organizers of five similar schemes across the United States, has applied to the NSF for a \$1.3-million grant to assess the schemes' effectiveness. He has already obtained some NSF money to develop the proposal.

GAO's 1994 report criticized the Department of Energy for the lack of formal studies on its programme's impact. Congress then shut down the programme, withdrawing \$15 million of annual support - about the same as is now spent on such schemes by all other sources combined. These programmes are not cheap to run. Columbia's costs $\$ 25,000$ per teacher over two years - half of it in teachers' stipends. But each teacher has hundreds of students, and an annual investment of $\$ 75$ million would allow every science teacher in the country to reconnect with science every thirteen years. Teachers love to learn science, but it will take hard data on student results to open the way for investment on that scale.

ColinMacilwain 